\title{
Impact of Wood Species, Dimensions and Drying Temperature on Sorption Behaviour of Wood
}

\section{Utjecaj vrste, dimenzija i temperature sušenja drva na njegovu sposobnost sorpcije}

\author{
Original scientific paper • Izvorni znanstveni rad \\ Received-prispjelo: 30. 7. 2013. \\ Accepted-prihvaćeno: 14. 1. 2015. \\ UDK: $630 * 812.22 ; 630 * 812.463$ \\ doi: $10.5552 /$ drind.2015.1369
}

\begin{abstract}
This research paper examines the interdependence between wood sorption properties and its dimensions, species and drying temperature. The research was carried out on specimens of six species of wood (oak, ash, aspen, birch, spruce and pine) which had different dimensions and were dried at temperatures ranging between 30 and $90^{\circ} \mathrm{C}$. Subsequently specimens underwent the moistening and air drying process, and the following parameters were recorded: moistening and drying rate, moisture content distribution, steady moisture content and sorption hysteresis. It was established that sorption hysteresis was most affected by the cross section dimensions of the specimen. It was determined that, when the thickness of wood specimens increases from 7 to $30 \mathrm{~mm}$, sorption hysteresis grows up to 8 times. The steady moisture content depends on the density, measurements and drying temperature of the specimen.
\end{abstract}

Key words: drying temperature, adsorption, desorption, moisture content, sorption hysteresis, water vapour

SAŽETAK • U ovom se istraživačkom radu ispituje međusobna ovisnost svojstva sorpcije drva i njegovih dimenzija, vrste drva i temperature sušenja. Istraživanje je provedeno na uzorcima izrađenima od šest vrsta drva (hrasta, jasena, jasike, bukve, smreke $i$ bora), različitih dimenzija, sušenih na temperaturama između $30 i 90{ }^{\circ} \mathrm{C}$. Uzorci su potom prošli proces vlaženja i sušenja na zraku te su bilježene vrijednosti ovih parametara: brzine vlaženja i sušenja, raspodjele sadržaja vode, stalnog sadržaja vode i histereze sorpcije. Utvrđeno je da su na histerezu sorpcije najviše utjecale dimenzije poprečnog presjeka uzorka. Tako je pri povećanju debljine uzoraka drva od 7 do $30 \mathrm{~mm}$, sorpcija histereze rasla do osam puta. Stalni sadržaj vode ovisi o gustoći, dimenzijama i temperaturi sušenja uzoraka.

Ključne riječi: temperatura sušenja, adsorpcija, desorpcija, sadržaj vode, histereza sorpcije, vodena para

\section{INTRODUCTION 1. UVOD}

Wood is a complex natural polymer which has a capillary, annular and layered structure. It is known that wood absorbs and evaporates water vapour, when it un- dergoes the moistening and drying processes. This results in sorption hysteresis, supposedly due to the difference in the sorbate filling and emptying of the pores (Popper et al., 2009). Usually a sorption isotherm is expressed as the function of wood moisture and relative humidity at a constant temperature. However, scientific

\footnotetext{
Authors are associate professors at Kaunas University of Technology, Department of Materials Engineering, Kaunas, Lithuania.

Autori su izvanredni profesori Tehnološkog sveučilišta u Kaunasu, Odjel za inženjerstvo materijala, Kaunas, Litva.
} 
studies and modelling show that ambient temperature has also influence on sorption/desorption processes and the size of the hysteresis loop (Merakeb et al., 2009). Wood drying is a complex process of heat and mass transfer, which is conditioned by some phenomena, such as heat/moisture exchange between wood and environment, and heat/moisture movement in wood (Kajalavičius, 2008). In the macrocapillary system, hygroscopic moisture moves only in the form of vapour (due to its partial pressure gradient), whereas in the microcapillary system, moisture moves in the form of both vapour and liquid (due to diffusion penetration).

A number of research projects have been carried out to evaluate the impact of various factors on wood sorption properties. The research (Esteban, 2010) examines sorption properties of Quercus spp. wood aged $5910 \pm 250 \mathrm{BP}$, which has been recently sawn and discovered underground. It was determined that, due to the physical and chemical changes in the cell wall, the equilibrium moisture content (EMC) of the unearthed wood was higher both in case of sorption and desorption. Another paper (Huang et al., 2009) focuses on how the acid/alkaline balance of wood $(\mathrm{pH})$ affects sorption properties of wood elements (cellulose and lignin). It was found that wood, which does not undergo chemical modification, absorbs lesser amounts of copper chloride under the same conditions than modified wood. A further paper (Nkolo Meze'e et al., 2008) explores the effect of temperature on sorption properties of wood exposed to water vapour at different temperatures $\left(20^{\circ} \mathrm{C}\right.$, $38^{\circ} \mathrm{C}, 50^{\circ} \mathrm{C}$ and $60^{\circ} \mathrm{C}$ ). It was established that sorption hysteresis is observed at all temperatures. In addition, the research revealed that changes in parameters, such as Gibbs energy, entropy and enthalpy, are negative in the presence of adsorption and positive in the presence of desorption, however, the amount of these changes hardly depends on temperature. Even when drying occurs at relatively low temperatures, there are residual phenomena which alter the further behaviour of wood. Higher temperature drying causes the following changes to the chemical composition of wood: hemicellulose, lignin and extractive substances begin to decompose, and cellulose becomes more crystalline (Esteves and Pereira, 2009). As a result of the reduced number of hydroxyl groups, wood tends to be more hydrophobic. Furthermore, due to a more crystalline structure of cellulose, water cannot easily enter cell walls of wood, which leads to a decrease in the EMC of heated wood (Akyildiz and Ates, 2008). The higher the temperature, the greater the change in the chemical structure of wood and the lower the EMC.

Scientists developed various mathematical models on the basis of which it would be possible to predict wood moisture content under changing conditions and moisture movement in wood (Svensson et al., 2011; Krabbenhoft and Damkilde, 2004). Other research papers provide two-dimensional and three-dimensional computer models imitating the wood drying process (Turner, 1996; Truscott and Turner, 2005). The paper by Merakeb et al. (2009) presents a model for wood sorption hysteresis, when wood undergoes moistening and drying in the environment of different parameters. A universal model was designed that can describe actual wood moistening/drying processes. Authors of another article carried out research into moisture movement in layered porous building structures (Johannesson and Janz, 2009). It was determined in the above mentioned papers that, when moisture moves in the form of both steam and water, sorption and desorption processes occur according to slightly different principles due to sorption hysteresis.

The examination of sorption properties of six species of wood (China fir, Japanese cedar, Western hemlock, red oak, red meranti and hard maple) under conditions of high relative humidity $(\mathrm{RH})$ allowed establishing that, when $\mathrm{RH}$ varied from $40 \%$ to $0 \%$, there was no noticeable difference in the EMC, however, when $\mathrm{RH}$ changed from $100 \%$ to $50 \%$, some differences were observed: when RH was lower than $90 \%$, coniferous wood had a higher moisture content in comparison to hardwood; however, when RH was higher than $90 \%$, hardwood had higher EMC (Wang and Liau, 1998). The assessment of the effect of temperature on the EMC of Pine radiata wood under pure saturated steam conditions allowed determining that, when temperature increases, the EMC decreases in a linear dependence (Pearson et al., 2012). Wood moisture sorption is also affected by wood properties (its species, density, etc.), therefore, the objective of this paper is to evaluate how drying temperatures and dimensions of specimens influence sorption behaviour of wood.

\section{MATERIALS AND METHODS} 2. MATERIJALI I METODE

Tests involved the use of the highest quality, branch, crack and other visible defect-free specimens of deciduous (oak (Quercus robur L.), ash (Fraxinus excelsior L.), aspen (Populus tremula L.), birch (Betula L.)) and coniferous (spruce (Picea abies L.), pine (Pinus sylvestris L.)) wood with the following densities: 777.3, 623.9, 453.6, 627.1, 487.3, $490.3 \mathrm{~kg} / \mathrm{m}^{3}$, respectively. Each wood species was represented by 30 specimens with the following dimensions: $450 \times 50 \times 30$ $\mathrm{mm}$. In order to assess the effect of specimen thickness on drying, 4 separate groups of 30 birch specimens were formed with the following thickness variations: $7 \mathrm{~mm}, 12 \mathrm{~mm}, 25 \mathrm{~mm}, 30 \mathrm{~mm}$, respectively. The length and width of these specimens were analogous to the ones of other specimens $(450 \mathrm{~mm}$ in length and $50 \mathrm{~mm}$ in width). Prior to the start of tests, specimens underwent conditioning at the temperature of $25^{\circ} \mathrm{C}$ and relative humidity ranging from 58 to $60 \%$. After the exposure to conditioning their moisture was $10.8 \pm 0.7 \%$.

\subsection{Equipment}

2.1. Oprema

Specimens underwent moistening and drying in an environmental chamber, where temperature and relative humidity were maintained to an accuracy of $1{ }^{\circ} \mathrm{C}$ and $1 \%$, respectively. In order to ensure the uniform distribution of air parameters, a circulation system was 
installed (air velocity $0.5-1.0 \mathrm{~m} / \mathrm{s}$ ). Wood moisture content was established applying a weighing method to a precision of $0.1 \%$. Changes in dimensions of specimens were recorded using an electronic sliding calliper with an accuracy of $0.01 \mathrm{~mm}$.

\subsection{Wood sorption / desorption studies}

\subsection{Ispitivanja sorpcije / desorpcije drva}

After the exposure to conditioning, specimens underwent moistening for 70 days at $30{ }^{\circ} \mathrm{C}$ and $90 \%$ relative humidity. Afterwards they were subjected to drying for 20 days at the temperature of $30{ }^{\circ} \mathrm{C}$ and $30 \%$ relative humidity. Birch specimens of different thickness were subjected to drying at the temperature of $60{ }^{\circ} \mathrm{C}$ and $6 \%$ relative humidity. Specimens were exposed to moistening and drying until they reached steady moisture content.

In order to evaluate the effect of drying temperature on wood sorption properties, oak, ash, pine, spruce and aspen specimens were divided into three groups $(1.1 ; 1.2 ; 1.3)$, and each group underwent drying at different temperatures (the first group at the temperature of $30^{\circ} \mathrm{C}$, the second group at the temperature of $60{ }^{\circ} \mathrm{C}$ and the third group at the temperature of $90{ }^{\circ} \mathrm{C}$ ) and $30 \%$ relative humidity. Then specimens were subjected to conditioning for a two week period at $20^{\circ} \mathrm{C}$ and $55 \pm 5 \%$ relative humidity and were repeatedly exposed to moistening at $30{ }^{\circ} \mathrm{C}$ and $90 \%$ relative humidity. Subsequently specimens were dried at $30{ }^{\circ} \mathrm{C}$ and $30 \%$ relative humidity. In order to assess changes in moisture and dimensional stability, specimens underwent mass and dimensional measurement.

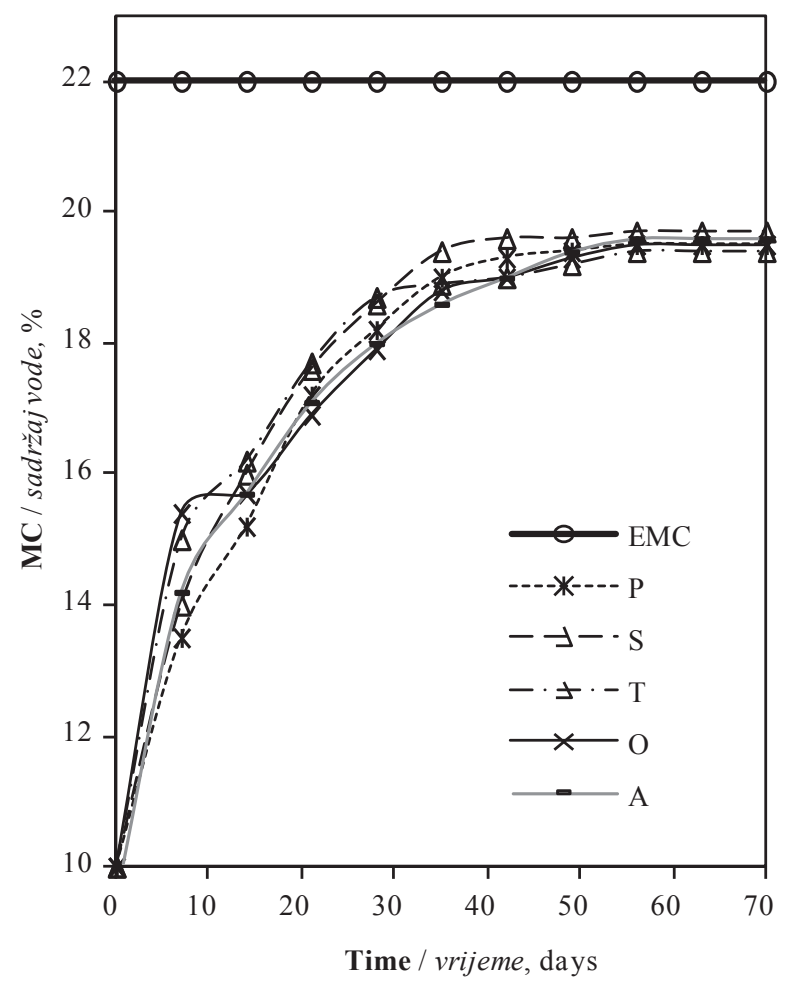

a)

\section{RESULTS}

3. REZULTATI

\subsection{Adsorption}

3.1. Adsorpcija

Figure 1 shows changes in moisture content of specimens of different wood species (a) and of different dimensions (b) by storing them in an environmental chamber for 70 days at $30{ }^{\circ} \mathrm{C}$ and $90 \%$ relative humidity. The equilibrium moisture content of wood should be approximately $22.0 \%$ in this case (Sergovskij and Rasev, 1987).

Figure 1(a) reveals that the highest moisture content was adsorbed during the first 7 days, i.e. moisture content alteration was up to $54 \%$. The largest change in moisture content was observed in oak specimens (54\%), the smallest change occurred in pine specimens $(35 \%)$; however, as a result of the further moistening process, oak wood adsorbed a noticeably lower moisture amount than other wood species. It was determined that during the moistening process all species of wood specimens, which were $30 \mathrm{~mm}$ thick, achieved a steady moisture content within 7 weeks (this moisture content ranged from 19.2 to $19.6 \%$ and specimens failed to reach the theoretical moisture content). Fig. 1 shows (b) that thinner specimens achieved this moisture content in a shorter period of time, i.e. within 5-6 weeks. Furthermore, in comparison to $30 \mathrm{~mm}$ thick specimens, thinner specimens had higher steady moisture content as follows: $25 \mathrm{~mm}-7 \%, 12 \mathrm{~mm}-13 \%$, and $7 \mathrm{~mm}-20 \%$, respectively.

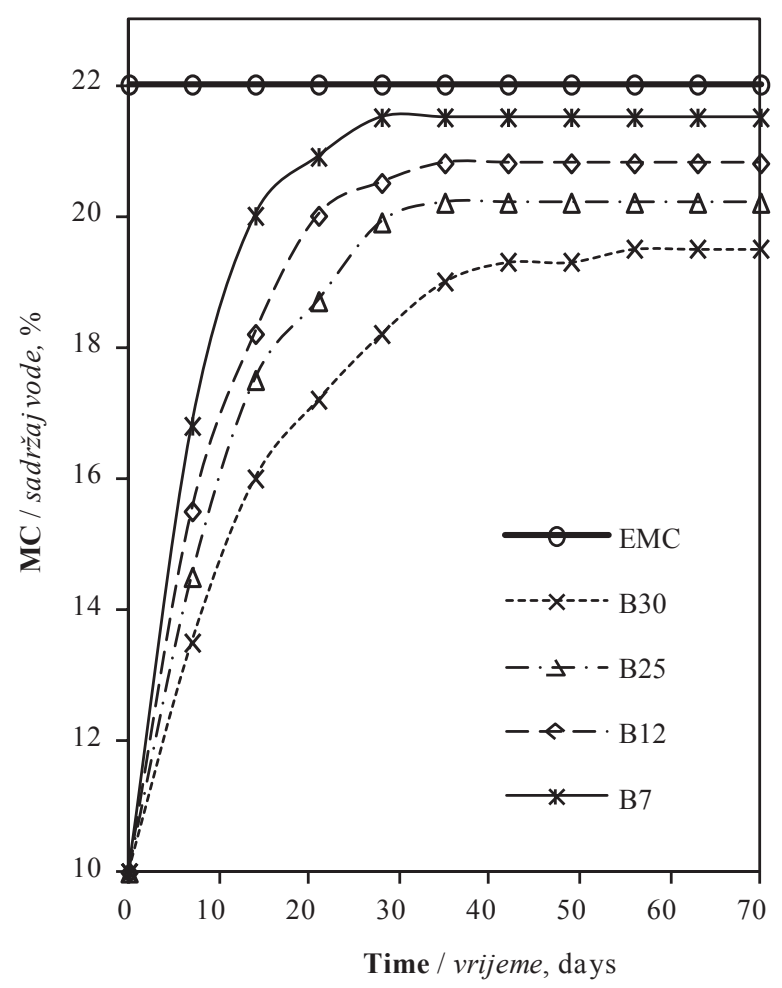

b)

Figure 1 Changes in wood moisture content during the moistening process: a) oak $(\mathrm{O})$, ash $(\mathrm{A})$, spruce $(\mathrm{S})$, pine $(\mathrm{P})$ and aspen (T) specimens; b) birch (B) specimens

Slika 1. Promjene sadržaja vode drva tijekom procesa vlaženja: a) uzorci hrasta $(\mathrm{O})$, jasena $(\mathrm{A})$, smreke $(\mathrm{S})$, bora $(\mathrm{P})$ i jasike (T); b) uzorak breze (B) 


\subsection{Desorption}

\subsection{Desorpcija}

Afterwards the same specimens underwent drying at the temperature of $30^{\circ} \mathrm{C}$ and $30 \%$ relative humidity, while birch specimens were dried at $60^{\circ} \mathrm{C}$ and $6 \%$ relative humidity. In this case the equilibrium moisture content should be $6.2 \%$ and $2.2 \%$, respectively (Sergovskij and Rasev, 1987). Figure 2 reveals changes in wood moisture content depending on drying duration and specimen thickness. Figure 2 (a) shows that the drying tendencies of $30 \mathrm{~mm}$ thick specimens of different types of wood were similar and wood did not reach the equilibrium moisture content. It was found that the moisture content of specimens ranged between 7.1 and $7.5 \%$ and differed from the equilibrium moisture content by $0.9-1.3 \%$.

It was found (Fig. 2, b) that during the drying process birch specimens of $30 \mathrm{~mm}$ thickness also failed to reach the theoretical equilibrium moisture content and had $3.3-3.4 \%$ moisture content after the drying period of 20 days, whereas, thinner specimens $(7 \mathrm{~mm}, 12 \mathrm{~mm}$, $25 \mathrm{~mm}$ ) achieved this theoretical equilibrium moisture content $(2.2 \%)$. In addition, 7 and $12 \mathrm{~mm}$ thick birch specimens reached this moisture content within $8-10$ days and in the case of $25 \mathrm{~mm}$ thick specimens it was achieved within $10-12$ days. These processes occur due to the moisture content gradient (Eq. 1), since wood specimens have uniform distribution of temperature and pressure, and their moisture content does not exceed the fibre saturation point (Kajalavičius, 2008).

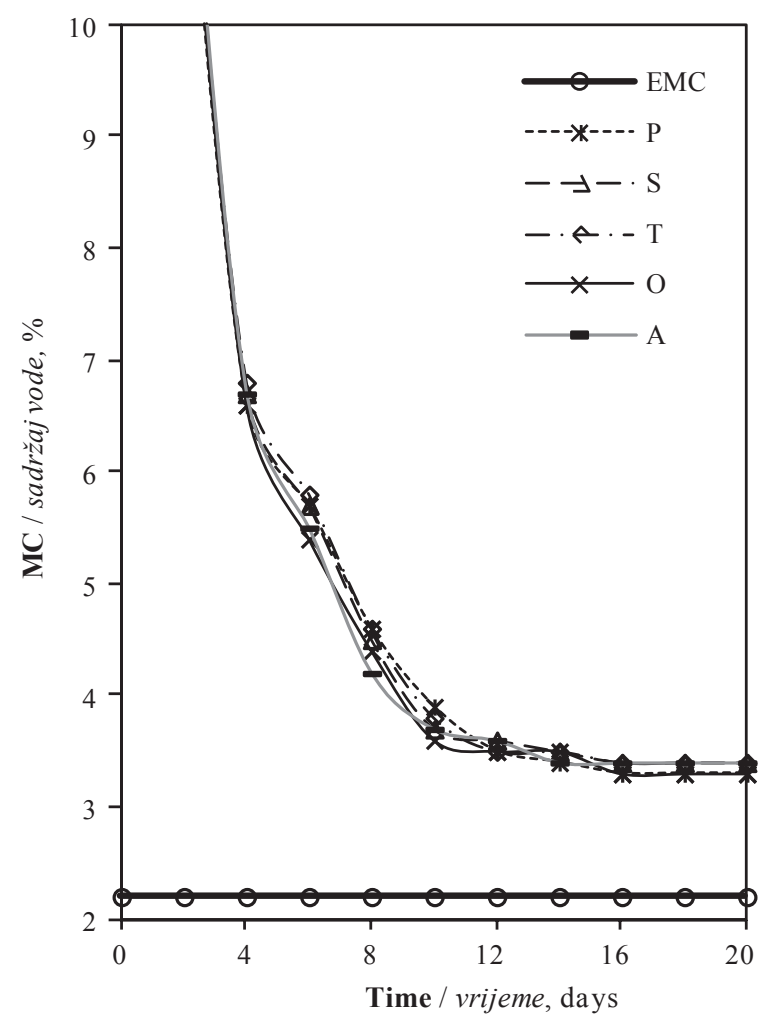

a)

$$
i=-a^{\prime} \cdot \rho_{0} \cdot \frac{d u}{d x}
$$

here $i$ - moisture flux density; $a^{\text {' }}$ - moisture diffusion coefficient; $\rho_{O}-$ wood density when moisture is $0 \%$; $\frac{d u}{d x}$ - moisture content gradient.

\subsection{Drying impact}

3.3. Utjecaj sušenja

In order to examine the effect of drying temperature on wood sorption properties, specimens underwent drying at different temperatures without air moistening. Oak, ash, pine, spruce and aspen specimens assigned to subgroup 1.1 were subjected to drying at the temperature of $30{ }^{\circ} \mathrm{C}$ until they reached steady moisture content conditions, specimens attributed to subgroup 1.2 were exposed to drying at the temperature of $60{ }^{\circ} \mathrm{C}$ and specimens attached to subgroup 1.3 were dried at the temperature of $90^{\circ} \mathrm{C}$ during the same period of time. Table 1 provides mean moisture content of specimens of the above-mentioned groups and the range of moisture content values of each subgroup after drying. The initial moisture content of wood specimens was $12 \% \pm 0.5 \%$.

Table 1 shows that, when specimens underwent drying at the temperature of $30^{\circ} \mathrm{C}$, they achieved $10.2-$ $11.2 \%$ moisture content after a two week period, and when they were subjected to drying at the temperature of $90{ }^{\circ} \mathrm{C}, 1.9-2.5 \%$ moisture content was reached during the same period of time. When the range of

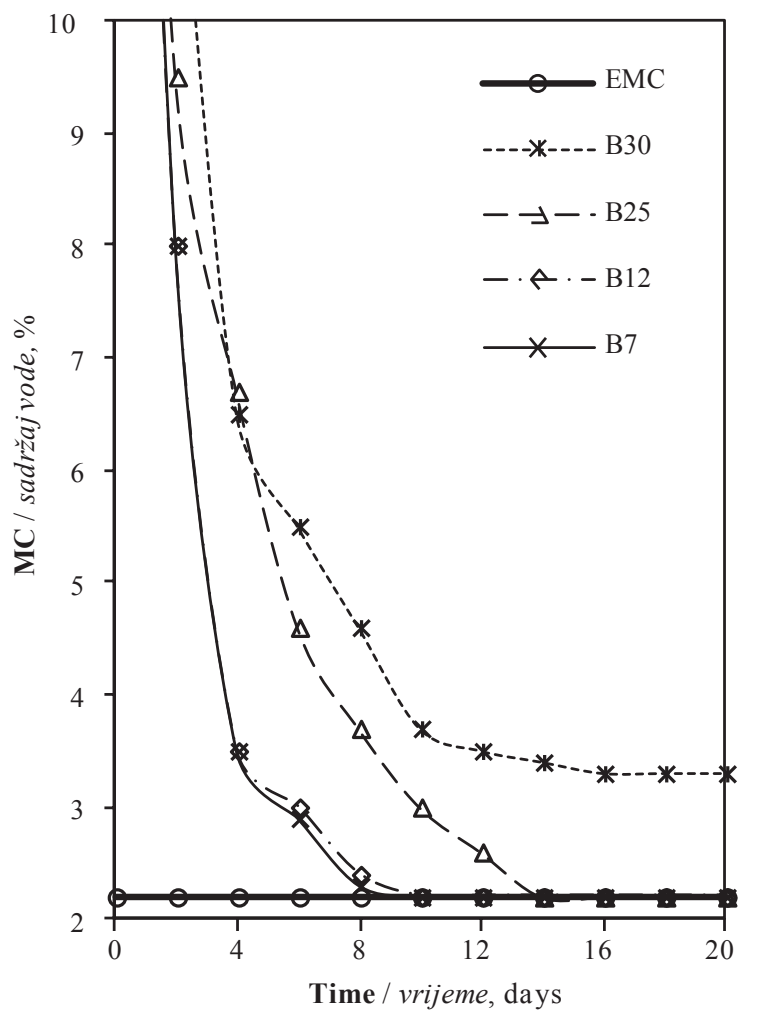

b)

Figure 2 Changes in wood moisture content during the drying process: a) oak $(\mathrm{O})$, ash $(\mathrm{A})$, spruce $(\mathrm{S})$, pine $(\mathrm{P})$ and aspen $(\mathrm{T})$ specimens; b) birch (B) specimens

Slika 2. Promjene sadržaja vode drva tijekom procesa sušenja: a) uzorci hrasta (O), jasena (A), smreke (S), bora (P) i jasike (T); b) uzorak breze (B) 
Table 1 Mean moisture content of specimens dried at different temperatures and the range of moisture content values (coefficient of variation)

Tablica 1. Prosječna količina sadržaja vode u uzorcima sušenim pri različitim temperaturama te raspon vrijednosti sadržaja vode (koeficijent varijacije)

\begin{tabular}{|l|c|c|c|}
\hline \multirow{4}{*}{$\begin{array}{c}\text { Wood species } \\
\text { Vrsta drva }\end{array}$} & $\begin{array}{c}\text { Drying at } \\
\mathbf{3 0}{ }^{\circ} \mathbf{C} \\
\text { Sušenje } \\
\text { pri } 30^{\circ} \mathrm{C}\end{array}$ & $\begin{array}{c}\text { Drying at } \\
\mathbf{6 0}^{\circ} \mathbf{C} \\
\text { Sušenje } \\
\text { pri } 60^{\circ} \mathrm{C}\end{array}$ & $\begin{array}{c}\text { Drying at } \\
\mathbf{9 0}{ }^{\circ} \mathbf{C} \\
\text { Sušenje } \\
\text { pri } 90^{\circ} \mathrm{C}\end{array}$ \\
\cline { 2 - 4 } & $\begin{array}{c}\mathrm{MC}, \% \\
\text { (Coef. of } \\
\text { Var.) }\end{array}$ & $\begin{array}{c}\mathrm{MC}, \% \\
\text { (Coef. of } \\
\text { Var.) }\end{array}$ & $\begin{array}{c}\mathrm{MC}, \% \\
\text { (Coef. of } \\
\text { Var.) }\end{array}$ \\
\hline \multirow{2}{*}{ Oak / Hrast } & 10.5 & 5.8 & 1.9 \\
& $(3.5)$ & $(3.4)$ & $(4.4)$ \\
\hline \multirow{2}{*}{ Ash / Jasen } & 10.8 & 5.7 & 2.5 \\
& $(3.7)$ & $(3.8)$ & $(4.0)$ \\
\hline \multirow{2}{*}{ Spruce / Smreka } & 11.2 & 4.7 & 2.2 \\
& $(3.3)$ & $(3.9)$ & $(4.4)$ \\
\hline \multirow{2}{*}{ Pine / Bor } & 10.8 & 5.7 & 2.3 \\
& $(3.5)$ & $(3.8)$ & $(4.1)$ \\
\hline \multirow{2}{*}{ Aspen / Jasika } & 10.2 & 4.5 & 2.2 \\
& $(3.7)$ & $(4.2)$ & $(4.5)$ \\
\hline
\end{tabular}

moisture content values was assessed, it was established that the greatest range of moisture content values was observed in specimens subjected to the highest temperature drying - the coefficient of variation ranged from 4.1 to $4.5 \%$, meanwhile, in the case of specimens dried at the temperature of $30^{\circ} \mathrm{C}$, the range of moisture content values was smaller by $17.8-19.5 \%$ - the coefficient of variation ranged from 3.3 to $3.7 \%$.

In order to evaluate changes in sorption behaviour of specimens dried at different temperatures, spec-

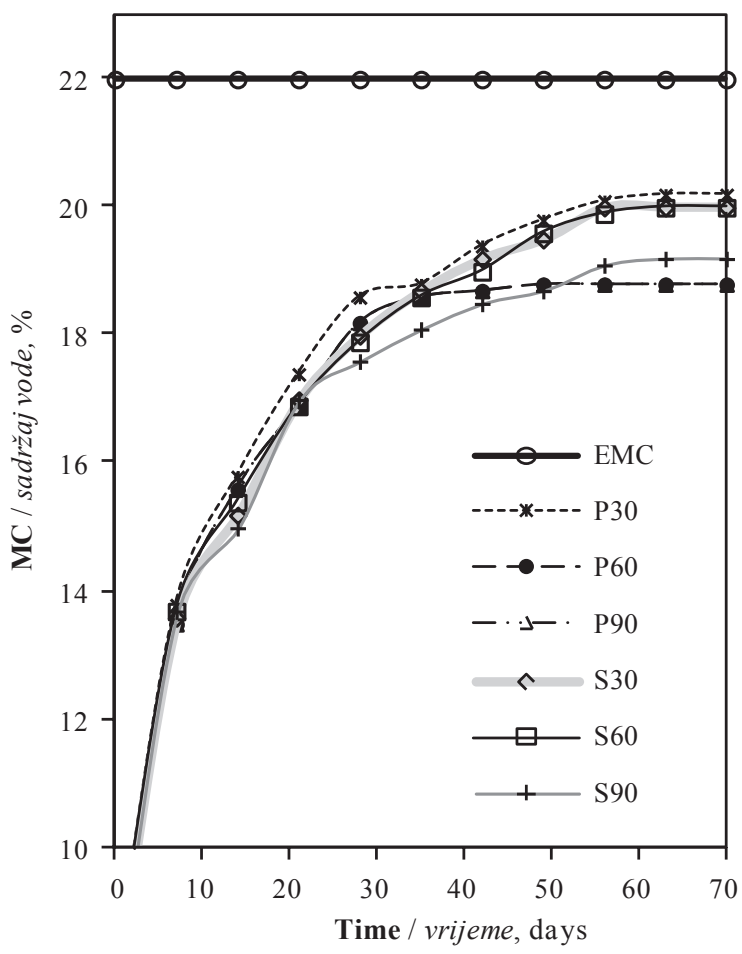

a) imens underwent conditioning for two weeks at $20^{\circ} \mathrm{C}$ and $50-60 \%$ relative humidity, and achieved $8 \% \pm$ $0.5 \%$ moisture content. Afterwards specimens were exposed to moistening at $30{ }^{\circ} \mathrm{C}$ and $90 \%$ relative humidity. Figure 3 reveals the main principles of changes occurring in moisture content of specimens during the moistening process.

Figure 3 shows that, when specimens underwent the moistening process, they adsorbed the highest moisture content during the first week. The mean moisture content of coniferous wood increased from 7.8-8.0\% to $13.6-13.9 \%$, i.e. approximately $74 \%$, and the average moisture content of deciduous wood rose from 8.0 -8.3 to $11.8-12.1 \%$, i.e. about $48 \%$. Specimens subjected to drying at the temperature of 30 and $60{ }^{\circ} \mathrm{C}$, achieved a steady moisture content within 56 days. In the case of coniferous wood, this moisture content was $20.1 \%$ on average at respective drying temperatures and in the case of deciduous wood it was 19.8 and $19.6 \%$ at respective drying temperatures. Specimens exposed to drying at the temperature of $90{ }^{\circ} \mathrm{C}$, reached a steady moisture content within 63 days. In the case of coniferous wood it was $19.0 \%$ and in the case of deciduous wood it was $19.2 \%$ on average.

Figure 3 (b) reveals that, when deciduous wood reaches moisture content up to $14 \%$, aspen and ash specimens, in contrast to oak specimens, absorb noticeably higher moisture content up to the $14^{\text {th }}$ day of the moistening process (after 7 days the moister content reached by aspen and ash specimens was higher by $15 \%$ and $10 \%$ than the one absorbed by oak specimens). This can be explained by different densities of oak, ash and aspen wood (density of oak wood was

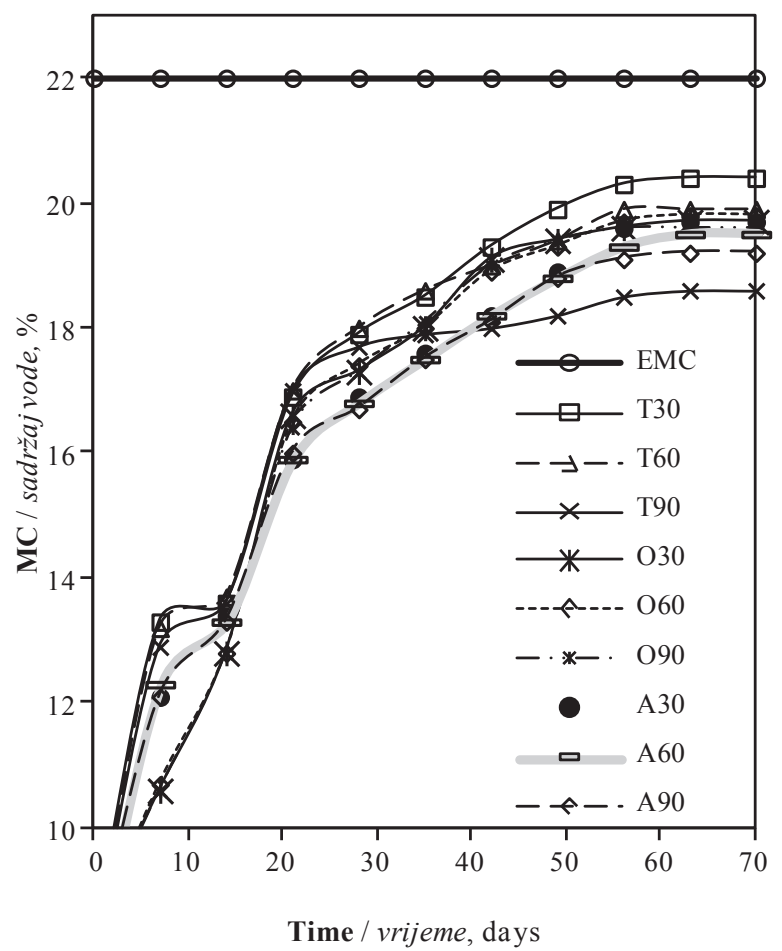

b)

Figure 3 Changes in moisture content of specimens dried at different temperatures during the moistening process: a) coniferous wood, $\mathrm{P}$ - pine, $\mathrm{S}$ - spruce; b) deciduous wood, $\mathrm{T}$ - aspen, $\mathrm{O}$ - oak, A - ash Slika 3. Promjene sadržaja vode u uzorcima sušenim pri različitim temperaturama tijekom procesa vlaženja: a) crnogorično drvo, P - bor, S - smreka; b) bjelogorično drvo, T - jasika, O - hrast, A - jasen 


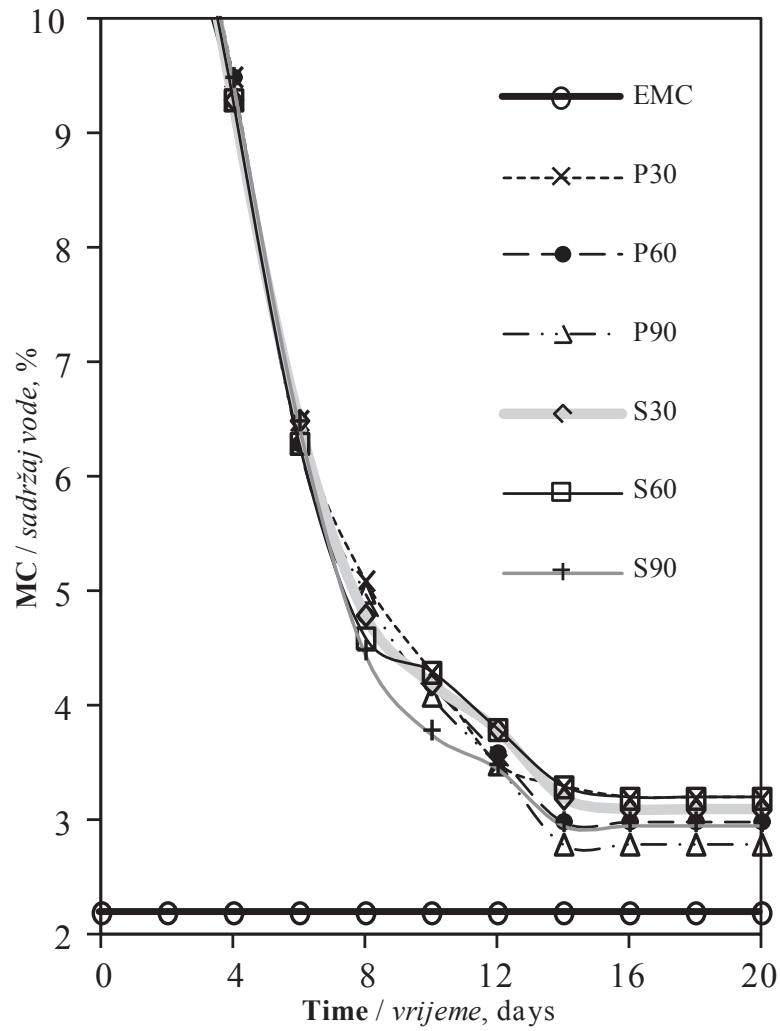

a)

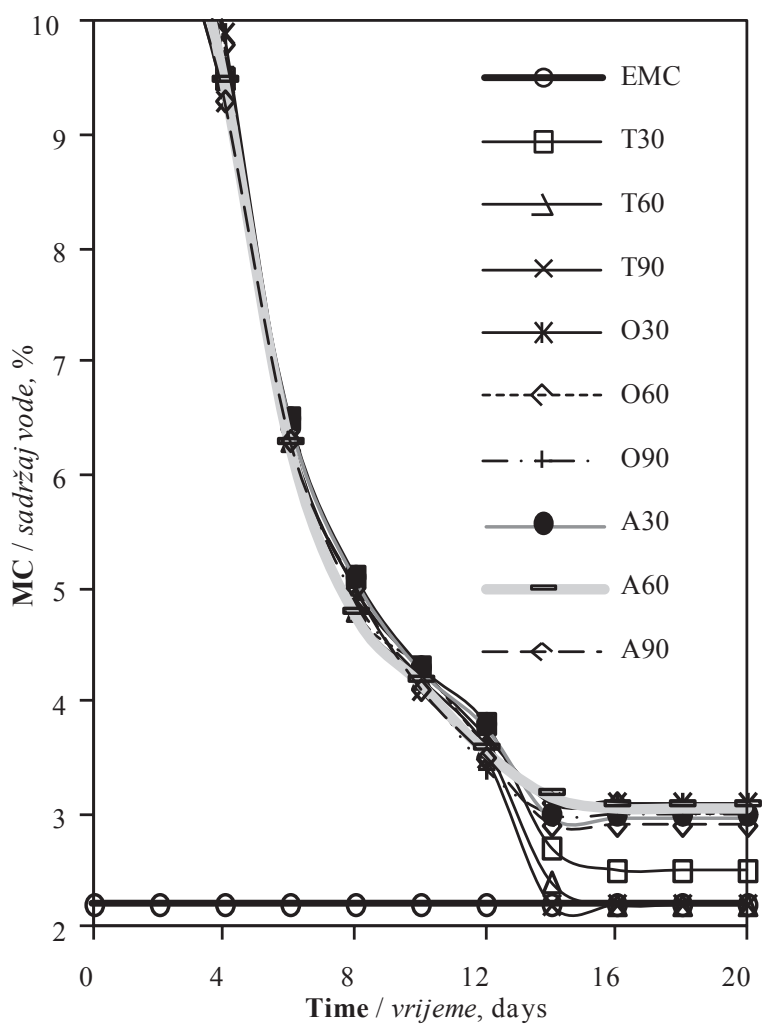

b)

Figure 4 Changes in moisture content of specimens dried at different temperatures during the drying process: a - coniferous wood, $\mathrm{P}$ - pine, $\mathrm{S}$ - spruce; $\mathrm{b}$ - deciduous wood, $\mathrm{T}$ - aspen, $\mathrm{O}$ - oak, A - ash

Slika 4. Promjene sadržaja vode u uzorcima sušenim pri različitim temperaturama tijekom procesa sušenja: a) crnogorično drvo, P - bor, S - smreka; b) bjelogorično drvo, T - jasika, O - hrast, A - jasen

$20 \%$ higher than ash wood and $42 \%$ higher than aspen wood). The higher the density of wood, the smaller the internal surface of cell cavities, whose holes contain bound moisture. Meanwhile lower density wood is characterized by a relatively larger surface area, therefore at the beginning of the moistening process it adsorbs more moisture. This can be observed in the case of aspen and partially in the case of ash (see Figure 3 (b)). However, after some time moisture penetration into deeper layers of lower density wood becomes slower as a result of a smaller number of microcapillaries. In higher density wood, moisture adsorption tends to be slower but steadier. Subsequently the moisture content becomes equal and similar to the one of deciduous wood until the $21^{\text {st }}$ day.

Afterwards, specimens underwent drying at 30 ${ }^{\circ} \mathrm{C}$ and $30 \%$ relative humidity. Figure 4 shows the main principles of changes in moisture content of specimens during the drying process.

When specimens were exposed to drying, the largest change in moisture content was recorded during the first 6 days: the moisture content of specimens decreased by about $50 \%$ (from approximately $20.0 \%$ to $9.1-9.7$ $\%)$. Subsequently the drying process was slowed down. Specimens achieved steady moisture content within 14 -16 days. The figure reveals that, after exposure to the temperature of $90{ }^{\circ} \mathrm{C}$, coniferous and deciduous wood reached $6.8-7.2 \%$ and $6.2-7.0 \%$ moisture content, respectively. The mean moisture content of specimens dried at the temperature of $30{ }^{\circ} \mathrm{C}$ was $7.1-7.2 \%$ in the case of coniferous wood and $6.2-7 \%$ in the case of deciduous wood. Figure 4 also shows that coniferous specimens failed to reach the theoretical steady moisture and in the case of deciduous wood it was achieved only by aspen specimens.

\section{DISCUSSION AND CONCLUSIONS 4. RASPRAVA I ZAKLJUČCI}

Tests show that specimens with larger cross sections, in contrast to specimens with smaller cross sections, reach steady moisture content after longer periods of time. This occurs because the moisture content gradient was the only major force to drive moisture in the present case. In both sorption and desorption cases, specimens with larger cross sections have uneven distribution of moisture content and their deeper layers fail to achieve the equilibrium moisture content (as a result of weaker forces that drive moisture). At the temperature of $30{ }^{\circ} \mathrm{C}$, sorption hysteresis depends on thicknesses of specimens: in the case of $30 \mathrm{~mm}$ thick birch specimens, the change in hysteresis was 3.5-3.8 $\%$, and in the case of $25 \mathrm{~mm}, 12 \mathrm{~mm}$ and $7 \mathrm{~mm}$ thick birch specimens, it was $1.8 \%, 1.2 \%$ and $0.5 \%$, respectively. In addition, sorption behaviour is also affected by drying temperatures of specimens. Specimens with uniform cross sections, which undergo drying at higher temperatures during the same period of time, reach lower moisture content (specimens dried at the temperature of $30{ }^{\circ} \mathrm{C}, 60^{\circ} \mathrm{C}$ and $90{ }^{\circ} \mathrm{C}$ achieved 
up to $10.2-11.2 \%, 4.5-5.8 \%$, and $1.9-2.5 \%$, respectively). Furthermore, the greatest range of moisture content values was observed in specimens with the lowest moisture content. This could be explained by different wood structure along the moisture transport direction. When wood is dried at higher temperatures, the distribution of moisture is more uneven along the cross-section of wood than it is in the case of low-temperature drying. Other research revealed that, when wood undergoes drying, wood cells are exposed to extremely high stresses and cell walls develop microcracks (Thuvander et al., 2001; Thuvander et al., 2002). Even when drying occurs at relatively low temperatures, there are residual phenomena that affect further behaviour of wood. It is known that subjecting wood to drying already at $50-60{ }^{\circ} \mathrm{C}$ leads to a decline in its hygroscopy (Sergovskij and Rasev, 1987).

Research showed that w,hen specimens underwent the moistening process, they adsorbed the highest amount of moisture during the first week. Besides, the mean moisture content of coniferous wood increased by $26 \%$ more than deciduous wood. This could be explained by the fact that the sorption rate of coniferous wood was higher than that of deciduous wood during this period due to different wood microstructure and chemical composition of coniferous and deciduous wood. The major portion of coniferous wood consists of tracheids, which may reach a length of roughly $5 \mathrm{~mm}$. Moisture can rather easily penetrate superficial layers of wood through cut open tracheids and later through bordered pit pairs into other cells. Deciduous wood is denser and its libriform fibre cells are only $1 \mathrm{~mm}$ in length, therefore, moisture penetration into wood layers is slower. Moreover, coniferous wood has more cellulose with free hydroxyl groups. Further wood moistening leads to substantially slower moisture penetration, as the moisture content of superficial layers of specimens approaches the fibre saturation point under those conditions and water molecules are forced to reach deeper layers.

Results revealed that, when specimens were subjected to drying, the difference between the equilibrium moisture content and steady moisture content of coniferous wood and deciduous wood was $1.8-2.0 \%$ and 1.6 $-2.3 \%$, respectively, and when specimens were exposed to drying at the temperature of $90{ }^{\circ} \mathrm{C}$, it was $2.8-3.2 \%$ and $2.4-3.4 \%$, respectively. When wood specimens were dried at the temperature of $30{ }^{\circ} \mathrm{C}$ and $90{ }^{\circ} \mathrm{C}$, sorption hysteresis for coniferous wood was 2.8 $-3.0 \%$ and $3.1-3.6 \%$, respectively, and for deciduous wood $1.9-3.2 \%$ and $3.0-3.4 \%$, respectively. Obviously thickness of the specimens, but not drying (heating) temperature, has a greater effect on the width of the hysteresis loop. Research carried out by other authors demonstrates that ,after the completion of the drying process, moisture is unevenly distributed along the cross-section of specimens (internal layers retain more moisture than external layers), which results in the formation of internal stresses (Kowalski and Musielak, 1999). Specimens with smaller cross-sections tend to have more considerable shrinkage/swelling on a relative basis (Stöhr, 1988). It is known that there is dependence between the hysteresis loop and the measurements of the specimen (Sergovskij and Rasev, 1987). The smaller the cross-section of the specimen, the smaller the hysteresis loop. The research also showed that coniferous specimens failed to reach the theoretical steady moisture, and in the case of deciduous wood, it was achieved only by aspen specimens. This can be explained by the existing hysteresis loop during drying process and by the fact that coniferous wood and lower density wood have better moisture and gas permeability (especially across the fibre) (Kajalavičius, 2008). Since the moisture content gradient was the only major force to drive moisture in the present case, it was probably insufficient to ensure the moisture content that would be even and equal to the equilibrium moisture content through the entire cross section. Tests reveal that, in the presence of higher temperature drying, the total pressure gradient has significant effect on the moisture transport phenomena (Remki et al., 2012).

The obtained results demonstrate that wood, which has different measurements and undergoes drying at different temperatures, is characterized by different sorption behaviour. This is relevant when it is necessary to examine the probable behaviour of wood and to exploit wood under certain conditions.

\section{REFERENCES}

\section{LITERATURA}

1. Akyildiz, M. H.; Ates, S., 2008: Effect of Heat Treatment on Equilibrium Moisture Content (EMC) of Some Wood Species in Turkey. Research Journal of Agriculture and Biological Sciences, 4(6): 660-665.

2. Esteban, L. G. et al., 2010: Effects of burial of Quercus spp. wood aged 5910 $\pm 250 \mathrm{BP}$ on sorption and thermodynamic properties. International Biodeterioration \& Biodegradation, 64: 371-377. http://dx.doi.org/10.1016/j.ibiod.2010.01.010

3. Esteves, B. M.; Pereira, H. M., 2009: Wood Modification by Heat Treatment: a Review. Bioresources, 4 (1): 370-404.

4. Huang, L. et al., 2009: Sorption of copper by chemically modified aspen wood fibers. Chemosphere, 76: 1056-1061. http://dx.doi.org/10.1016/j.chemosphere.2009.04.030

5. Johannesson, B.; Janz, M., 2009: A two-phase moisture transport model accounting for sorption hysteresis in layered porous building constructions. Building and Environment, 44: 1285-1294.

http://dx.doi.org/10.1016/j.buildenv.2008.09.018

6. Kajalavičius, A., 2008: Medienos hidroterminio apdorojimo teorija ir ịranga [Theory and equipment of wood hydrothermal processing]). Kaunas, Technologija 167 p. (in Lithuanian).

7. Kowalski, S. J.; Musielak, G., 1999: Deformations and Stresses in Dried Wood. Transport in Porous Media, 34: 239-248. http://dx.doi.org/10.1023/A:1006573727751

8. Krabbenhoft, K.; Damkilde, L., 2004: A model for nonFickian moisture transfer in wood. Materials and Structures, 37: 615-622.

http://dx.doi.org/10.1007/BF02483291

9. Menze'e, Y. N.; Ngamveng, J. N.; Bardet, S., 2008: Effect of enthalpy - entropy compensation during sorption of water vapour in tropical woods: The case of Bubinga (Guibourtia Tessmanii J. Leonard; G. Pellegriniana J. L.). Thermochimica Acta, 468 (1-2): 1-5. http://dx.doi.org/10.1016/j.tca.2007.11.002 
10. Merakeb, S.; Dubois, F.; Petit, Ch., 2009: Modeling of the sorption hysteresis for wood. Wood Sci Technol, 43: 575-589. http://dx.doi.org/10.1007/s00226-009-0249-2

11. Pearson, H.; Gabbitas, B.; Ormarsson, S., 2012: Equilibrium moisture content of radiata pine at elevated temperature and pressure reveals measurement challenges. Journal of Materials Science, 48(1): 332-341. http://dx.doi.org/10.1007/s10853-012-6750-2

12. Popper, R.; Niemz, P.; Croptier, S., 2009: Adsorption and desorption measurements on selected exotic wood species. Analysis with the hailwood-horrobin model to describe the sorption hysteresis. Wood research, 54(4): 43-56.

13. Remki, B.; Abahri, K.; Tahlaiti, M.; Belarbi, R., 2012: Hygrothermal transfer in wood drying under the atmospheric pressure gradient. International Journal of Thermal Sciences, 57: 135-141. http://dx.doi.org/10.1016/j.ijthermalsci.2012.02.005

14. Sergovskij, P. S.; Rasev, A. I., 1987: Hidrotermičeskaja obrabotka i konservirovanije drevesiny [Hydrothermal Treatment and Preservation of Wood]. Moscow, Lesnaja promišlennost 360 p. (in Russian).

15. Stöhr, H. P., 1988: Shrinkage differential as a measure for drying stress determination. Wood Science and Technology, 22: 121-128. http://dx.doi.org/10.1007/BF00355848

16. Svensson, S.; Turk, G.; Hozjan, T., 2011: Predicting moisture state of timber members in a continuously varying climate. Engineering Structures, 33: 3064-3070. http://dx.doi.org/10.1016/j.engstruct.2011.04.029

17. Thuvander, F.; Kifetew, G.; Berglund, L. A., 2002: Modelling of Cell Wall Drying Stresses in Wood. Wood Science and Technology, 36: 241-254.

http://dx.doi.org/10.1007/s00226-001-0134-0
18. Thuvander, F.; Wallström, L.; Berglund, L. A.; Lindberg, K. A. H., 2001: Effects of an impregnation procedure for prevention of wood cell wall damage due to drying. Wood Science and Technology, 34: 473-480.

http://dx.doi.org/10.1007/s002260000065

19. Truscott, S. L.; Turner, I. W., 2005: A heterogeneous three-dimensional computational model for wood drying. Applied Mathematical Modelling, 29: 381-410. http://dx.doi.org/10.1016/j.apm.2004.09.008

20. Turner, I. W., 1996: A two-dimensional orthotropic model for simulating wood drying processes. Applied Mathematical Modelling, 20 (1): 60-81.

http://dx.doi.org/10.1016/0307-904X(95)00106-T

21. Wang, S.-Y.; Liau, Ch. F., 1998: Assessment of hygroscopic conditioning performance of interior decorative materials IV: Sorption characteristics of wood under high relative humidity condition. Journal of Materials Science, 44: 260-266.

http://dx.doi.org/10.1007/BF00581305

\section{Corresponding address:}

Assoc. Prof. DARIUS ALBREKTAS, Ph. D.

Department of Materials Engineering

Kaunas University of Technology

Studentų str. 56

LT-51424 Kaunas, LITHUANIA

e-mail: darius.albrektas@ktu.lt 